\title{
URGENCY OF MARRIAGE REGULATION BETWEEN CIVIL STATE EMPLOYEES AND FOREIGN CITIZENS
}

\section{Dewi Masyitha}

\author{
Faculty of Law, Universitas Indonesia \\ Jl. Salemba Raya No.4, Jakarta, Indonesia 10430 \\ Email:dewi.masyitha@ui.ac.id
}

\begin{abstract}
Submitted : 14/01/2021 Reviewed:29/03/2021 Accepted:31/03/2021
Abstract: Mixed marriage has become a common thing nowadays, but the arrangement in Indonesia is still limited. Even until now there has been no regulation regarding mixed marriages between Civil Servants and Foreign Citizens, even though their status as Civil Servants has various special consequences. Thus, there is a need for a special arrangement to accommodate the rights and obligations of perpetrators of mixed marriages between civil servants and foreign citizens. This type of research uses a normative juridical approach. Based on this research, it can be concluded that the urgency of establishing a regulation on mixed marriage between civil servants and foreigners is needed as a guide for civil servants in fulfilling their rights and obligations and their implementation needs to be outlined in the revision of PP. 10 of 1983 and PP. 7 of 1977.
\end{abstract}

Keywords: Mixed Marriage; Government employees; Foreign Citizens

DOI: 10.32801/lamlaj.v6i1.236

\section{INTRODUCTION}

This paper will discuss about mixed marriages between Indonesian citizens and foreigners which are increasing along with globalization. However, it will focus on mixed marriages that occur between Indonesian citizens who work as civil servants and foreigners. The arrangement of mixed marriage between civil servants and foreigners basically cannot be equated with conventional marriage arrangements and a special arrangement needs to be made, so that civil servants do not experience difficulties in knowing their rights and obligations as civil servants even though they have married foreigners. The making of a special arrangement regarding mixed marriages between civil servants and foreigners can make it easier for civil servants to obtain legal certainty in fulfilling their rights so that the elements of justice and legal benefits can be fulfilled.

Marriage according to Kaharuddin is an agreement and bond between man and woman to live together legally as husband and wife 
and form a happy and eternal household. ${ }^{1}$ According to Article 1 of Law No.1 of 1974 concerning Marriage (Law No.1 / 1974), the definition of marriage is a form of physical and spiritual bond between a man and a woman as husband and wife which aims to form a family or household happy and eternal based on the Supreme Lordship. Meanwhile, marriage according to the Islamic viewpoint is something that is obligatory, because marriage is one of the means to get sakinah in life (QS. Ar-Rum [30] verse 2) and it is through marriage that the offspring will be produced who will continue the relay of life in world as the word of Allah SWT in QS. Al-Furqon [25] verse 54, "And He it is Who created man from water, and then produced from him two sorts of kindred: by descent and by marriage. Your Lord is All-Powerful'". ${ }^{2}$ Although sometimes there is a difference between the terms nikah and "marriage", in principle marriage and marriage only differ in drawing their roots. ${ }^{3}$ So, the two terms can be said to have the same meaning and the use of the terms is interchangeable.

Getting married and forming a family is basically the right of every adult man and woman. The affirmation of this is stated in Article 28 B paragraph (1) of the second amendment to the 1945 Constitution of the

\footnotetext{
${ }^{1}$ Kaharuddin, Nilai-Nilai Filosofi Perkawinan: Menurut Hukum Perkawinan Islam dan UndangUndang RI Nomor 1 Tahun 1974 tentang Perkawinan (Jakarta: Mitra Wacana Media, 2015), 62.

2 Siska Lis Sulistiani, Kedudukan Hukum Anak: Hasil Perkawinan Beda Agama Menurut Hukum Positif dan Hukum Islam (Bandung: PT Refika Aditama, 2015), 1.

3 Menurut Kamal Mukhtar seperti yang dikutip oleh Wahyu Wibisana, "Pernikahan Dalam Islam," Jurnal Pendidikan Agama Islam -Ta'lim 14, no. 2 (2016): 186, http://jurnal.upi.edu/taklim/view/4607/ PERNIKAHAN\%20DALAM\%20ISLAM.
}

Republic of Indonesia where everyone has the right to form a family and continue their offspring through legal marriage, Article 10 paragraphs (1) and (2) of the Law Number 39 of 1999 concerning Human Rights (Human Rights Law) also emphasizes the right to marry where everyone has the right to form a family and continue their offspring through a legal marriage which can only take place on the free will of the prospective husband and wife. Even in the Islamic perspective, getting married is a part of worship or completing half of one's religion. Because after marriage, we tend to lower our gaze more and protect our genitals more.

As mentioned earlier, marriage is a human right for adults. Human rights according to the Human Rights Law are a set of rights inherent in the nature and existence of humans as creatures of God Almighty and are His gifts that must be respected, upheld, and protected by the state, law, Government, and everyone. for the honor and protection of human dignity. Therefore, the human right to marry must be protected by the state. This is also the mandate of the Indonesian Basic Constitution in protecting the human rights of its citizens.

One of the protections carried out by the state is by regulating the provisions regarding marriage through statutory regulations. In 1974, Law no. 1/1974 was passed, although there were pros and cons. Some of the articles in Law no. 1/1974 is administrative in nature, but there are also articles that refer to the Marriage Law in Burgerlijk Wetboek (BW) and Huwe-lijks Ordonantie Christen Indonesihes Java, Minahasa and Amboina (Stb. 1933 No. 74 jo. 1936 No. 607) (HOCI), which is in substance contrary to the essence of Islamic law. However, after going through various revisions, Law no. 1/1974 can be ratified and then 
followed by Government Regulation Number 9 of 1975 concerning the Implementation of Law Number 1 of 1974 concerning Marriage. ${ }^{4}$

Apart from general marriages such as marriage between Indonesian citizens, there is also what is known as mixed marriages. Indonesia itself has been familiar with the mixed marriage system since the colonial period. At that time, the Dutch government passed a mixed marriage regulation, namely Regeling op de gemengde Huwelijken S. 1898 No. 158 (GHR). Article 1 of GHR defines mixed marriage as, "Huwelij-ken tusschen personen, die in Indonesië aan een verschillend recht onderworpen zijn, worden gemengde huwelijken genoemd." Mixed marriages are marriages between people who in Indonesia are subject to different laws. However, after Law Number 1 Year 1974 was passed, GHR automatically no longer applies. Along with the development of the era marked by technological advances in the field of communication and transportation, and supported by the increasing mobility of the population between countries, the potential for mixed marriages between Indonesians and foreigners tends to increase.

Basically, everyone has the right to choose their partner to become husband / wife and build a family, because this is a human right that is owned by every human being, including civil servants. Although they must act as an apparatus who works and serves and must have full loyalty to the state, civil servants are not prohibited from engaging in mixed marriages or at least until now there has been no

\footnotetext{
4 Ahmad Rifai, Ibnu Sodiq, and Abdul Muntholib, "Sejarah Undang-Undang Perkawinan atas Pendapat Hingga Pertentangan dari Masyarakat dan Dewan Perwakilan Rakyat Tahun 1973-1974,', Journal of Indonesian History 4, no 1 (2015): 8, https://journal. unnes.ac.id/sju/index.php/jih/article/view/18401.
}

regulation that prohibits mixed marriages for civil servants. However, as a state official, civil servants have rights and obligations that can be affected by mixed marriages. For example, related to how the provision of family allowances with the status of foreigners or children who have dual citizenship status is limited, and even the potential for espionage.

Apart from the absence of specific arrangements regarding mixed marriages between civil servants and foreigners, literature including books, journals, and articles that specifically discuss mixed marriages between civil servants and foreigners in Indonesia are also still difficult to find. So, this topic is interesting for further research and is expected to be useful in the study of civil law science and open the way for further research on mixed marriages between civil servants and foreigners, especially to develop research subjects regarding the importance of the existence of mixed marriage arrangements between civil servants and foreigners.

Based on the description above, the problem can be formulated, namely the urgency of marriage arrangements between civil servants and foreigners, especially in terms of fulfilling the rights and obligations of civil servants and applying the ideal law for mixed marriages between civil servants and foreigners?

\section{METHOD}

This type of research uses a normative juridical approach which aims to analyze the application of legal principles and the harmonization of the implementation of statutory regulations, especially in the legal environment of employment, marriage, and citizenship.

Research is sourced from secondary data by conducting literature searches or literature 
studies of statutory regulations, books, journals, and other secondary data related to the research topic.

This type of data comes from secondary data, so data collection is carried out through the National Library and secondary data searches through journals and other literary materials on the internet. The analysis of legal materials is carried out using prescriptive analysis techniques.

\section{ANALYSIS AND DISCUSSION Arrangement of Mixed Marriages in Indo- nesia}

Like any marriage in general, mixed marriages also create legal relations which then have legal consequences. With the specific nature of mixed marriages, the legal consequences that arise will also be different from the legal consequences of marriage in general. The legal consequences of mixed marriages are not only regulated in Law no. 1/1974, but also in Law no. 12 of 2006 concerning Citizenship, and Law no. 6 of 2011 concerning Immigration.,

The legal consequences arising from mixed marriages include:

1. Obtaining the citizenship of their spouse or losing their citizenship (Article 58 of the Marriage Law and Article 26 of the Citizenship Law,);

2. Granting a limited stay permit with a limited stay visa for spouses who are foreigners (Article 39 letter a of the Immigration Law jo. Article 141 letter e Government Regulation Number 31 of 2013 concerning Implementation Regulations of the Immigration Law);

3. There is a mixture of assets marital, assets acquired during the marriage become joint assets. This causes a partner who is a for- eigner to also become the owner of joint assets, including land and / or buildings. Based on Article 35 paragraph (1) of the Law Marriage, so that the assets obtained during theperiod marriage, both movable and immovable assets become joint assets. So that the result of the law of marriage mixed is that foreigners can own and control land in Indonesia. ${ }^{5}$ Whereas Article 21 paragraph (3) of Law no. 5/1960 concerning Basic Agrarian Principles prohibits ownership of Property Rights, Business Use Rights, and Building Use Rights, so that this can cause the relevant Indonesian Citizen to lose their rights as well. Therefore, the Indonesian citizens concerned do not lose their rights, before marriage they can make a marriage agreement or a prenuptial agreement which regulates the separation of property belonging to husband and wife. The marriage agreement is made in notarial or under the hands of a marriage registrar, namely the Office of Religious Affairs or the Civil Registry Office. In its development, the practice of a marriage agreement can be carried out after the marriage takes place by submitting a request to the court and obtaining a court ruling that has permanent legal force. ${ }^{6}$ The Constitutional Court issued Decision No. 69 / PUU-XIII / 2015, which states that

\footnotetext{
Sayaman Harahap, "Penerapan Ketentuan Pasal 21 ayat (3) UUPA tentang Kepemilikan Tanah bagi WNI dalam Perkawinan Campuran," Jurnal IUS Kajian Hukum dan Keadilan 4, no. 3 (2016): 440, https:// jurnalius.ac.id/ojs/index.php/jurnalIUS/article/ view/328.

${ }^{6}$ Herni Widanarti, “Akibat Hukum Perkawinan Campuran Terhadap Harta Perkawinan (Penetapan Pengadilan Negeri Denpasar No: 536/Pdt.P/2015/ PN.Dps.)," Diponegoro Private Law Review 2, no. 1 (2018): 164, https://ejournal2.undip.ac.id/index.php/ dplr/article/view/2827.
} 
the marriage agreement can be carried out not only before marriage, but also during and during the marriage. This provision has also been used as a guideline by the Department of Population and Civil Registration through the Letter of the Director General of Population and Civil Registration No. 472.2 / 5876 / DUKCAPIL dated 19 May 2017.

When viewed from the consequences of the mixed marriage law above, regulations regarding mixed marriage in Indonesia are contained in several laws and regulations such as the Marriage Law, the Citizenship Law, and the Immigration Law, so that the arrangements are still fragmented. ${ }^{7}$ It can also be said that the rules for mixed marriage in this statutory law are still limited and inadequate. Arrangements for mixed marriages between civil servants and foreigners in these laws and regulations do not exist at all, even in the ASN and PP Law on Marriage Permit and Divorce for Civil Servants. The arrangement of mixed marriages in these statutory regulations can be detailed as follows:

1. Law no. $1 / 1974$

This Law only regulates mixed marriages

\footnotetext{
7 Padahal Indonesia pada masa kolonial telah memiliki satu peraturan perundang-undangan yang secara khusus mengatur mengenai perkawinan campuran, yaitu Regeling op de Gemengde Huwelijken (GHR) atau Peraturan tentang Perkawinan Campuran Penetapan Raja Tanggal 29 Desember 1896 No. 23-Stbl 1898 No. 158, Dir. Dandit. Dengan Stbl. 901/348, 1902/311, 1907/205, 1918/30, 159, 160, dan 161,1919/81, dan 816,1931/168 jo 423. Pengaturan tersebut dibuat karena pada masa itu banyak pedagang dari China, Arab, maupun Eropa yang pada akhirnya menetap dan menikah dengan penduduk asli Indonesia. GHR ini masih sempat berlaku hingga masa setelah kemerdekaan berdasarkan Pasal II Aturan Peralihan dalam UUD 1945 dan setelah disahkannya UU Nomor 1 Tahun 1974 tentang Perkawinan, GHR otomatis tidak berlaku lagi.
}

in six articles, namely Article 57 to Article 62, the provisions in these articles are only general in nature, such as the definition in Article 57, citizenship status and the delegation of regulations to the Citizenship Law, and the determination of the applicable law is regulated in Article 58 and Article 59, the fulfillment of the requirements for marriage before getting married in Article 60, however it is not explained in detail what the conditions for a mixed marriage are, but it can be assumed that the conditions of marriage mix refers to the conventional marriage requirements listed in Article 6 to Article 12 of the Marriage Law. Article 61 concerning marriage records, and Article 62 concerning the position of children;

2. UU no. 12/2006 concerning Citizenship of the Republic of Indonesia law This regulates the nationality status of perpetrators of marriages mixed in Article 26, Article 27, Article 32 paragraph (3) and (4), as well as regulates the status of children resulting from marriages mixed in Article 4 letter c, d, e, f, and i, as well as Article 25.

3. Law no. $6 / 2011$ concerning Immigration This law regulates several requirements for foreigners, especially those married to Indonesian citizens, to stay in Indonesia, including stipulated in Article 39 regarding the granting of limited stay visas, Article 52 regarding limited stay permits, Article 54, Article 60, Article 62 paragraph (2) letter g, and Article 141 letter $\mathrm{b}$ regarding permanent residence permit, Article 63 paragraph (4) and (5) regarding guarantee. 
The Urgency of Mixed Marriage Arrangements between Civil Servants and Foreigners

According to Sjamsu Alam, marriage arrangements are part of the ideals of law enforcement which are intended to create peaceful,living conditions peaceful, and just. The noble ideal of the law is a manifestation of one of the elements of human nature, which is the existence of relationship of attraction. natural between two different types of human beings, male and female. ${ }^{8}$

The absence of regulations that specifically regulate mixed marriages between civil servants and foreigners, so this noble ideal of law is difficult to create. Pompe also questioned the absence of clear formal regulations regarding mixed marriages which led to the confusion that prevailed in the subject. Can one conclude mixed marriages against the terms of religious marriage? If it turns out that social interaction between different religious groups cannot be prevented, doesn't the absence of strict legal rules on the subject affect legal certainty? ${ }^{9}$ In this case, Pompe focuses more on mixed inter-religious marriages. However, this is still relevant in mixed marriages that the author is discussing here. Therefore, there is an urgency for the forma-

${ }^{8}$ Andi Syamsualam, "Usia Perkawinan Dalam Perspektif Filsafat Hukum Dan Kontribusinya Bagi Pengembangan Hukum Perkawinan Indonesia," Kepaniteraan Mahkamah Agung RI, 2011, https:// kepaniteraan.mahkamahagung.go.id/index.php/ kegiatan/6-artikel/artikel-hakim-agung/188-usiaperkawinan-dalam-perspektif-filsafat-hukumdan-kontribusinya-bagi-pengembangan-hukumperkawinan-indonesia-dr-h-andi-syamsualam-sh-mh.

9 S. Pompe, "Mixed Marriages in Indonesia: Some Comments on The Law and The Literature," Bijdragen tot de Taal-, Land-en Volkenkunde 144, no. 2/3 (April 1, 1988): 261, http://www.jstor.org/ stable/27863947. tion of special arrangements for mixed marriages between civil servants and foreigners that can accommodate all matters including the rights and obligations of perpetrators of mixed marriages, so that there are elements of justice, benefits and legal certainty that can protect the perpetrators of mixed marriages. .

There are no specific arrangements that regulate mixed marriages between civil servants and foreigners, so that for now, inevitably, they have to follow mixed marriage arrangements in general, even though civil servants have the privilege of being a civil servant who carries out state duties. In fact, one of the functions of law in society is to accommodate differences in interests between individuals, where some of these interests are in line with the interests of individuals or other communities, but some are inconsistent and can lead to conflicts. ${ }^{10}$ This can cause protection for civil servants only half way and the potential for conflict will be high, so that the legal function is not functioning optimally.

If we look further, the arrangement for mixed marriages is more focused on the administrative side, even though mixed marriages are more than just administrative documents, but there are also rights and obligations arising from the relationship. Especially as civil servants who are state servants who have special rights and obligations, $\mathrm{it}^{11}$ can cause new problems. Therefore, there needs to be a special arrangement regarding mixed marriages between civil servants and foreigners which in detail regulates all aspects including the administrative process to the technical im-

\footnotetext{
${ }^{10}$ Amiruddin Pabbu and Rahman Syamsuddin, Pengantar Ilmu Hukum, (Jakarta: Penerbit Mitra Wacana Media, 2014), 74

${ }^{11}$ Hak dan kewajiban PNS sesuai yang tercantum dalam Pasal 21 dan Pasal 23 UU No. 5 Tahun 2014 tentang Aparatur Sipil Negara.
} 
plementation. Several reasons for the urgency of arranging mixed marriages between civil servants and foreigners, including:

1. To Arrange the requirements for foreigners before being able to marry civil servants.

This is related to loyalty to the state which can cause problems in marriages between civil servants and foreigners where the loyalty of civil servants to the state can be divided. Especially for civil servants working in the vital state institutions such as the Ministry of Defense, NIA Intelligence (National Agency), or ministries / agencies of vital, countries other can potentially emergence espionage gap (investigations in secret to the data of military and economic data of other countries). Even though this opinion is the result of thinking that may be considered too far, if it does happen, it has the potential to endanger the security of the country. So far, the requirements for mixed marriages have been equated with the requirements for marriage in Law no. 1/1974 in Article 6 to Article 12, including:

a. There is an agreement from the two prospective brides (Article 6 paragraph (1));

b. There is permission from both parents or guardians for those who have not reached the age of 21 (twenty one) years (Article 6 paragraph (2));

c. Marriage is only permitted if the man and woman have reached the age of 19 (nineteen) years (Article 7 paragraph (1) Law No. 16/2019 concerning Amendments to Law No. 1/1974);

d. The bride and groom are not relat- ed by blood / family who cannot be married (Article 8);

e. Not being in abond marriage with another person (Article 9);

f. Husbands and wives who are divorced remarry with each other for the second time, it is prohibited remarriage (Article 10);

g. If the prospective bride is a widow, it is not within the waiting time (Article 11).

2. In addition, before being able to marry an Indonesian citizen, foreigners only need to meet administrative requirements in the form of: ${ }^{12}$

a. CNI (Certificate of No Impediment), which is a certificate that you stating can marry and will marry an Indonesian citizen. This letter is issued by the competent authority in the country, such as an embassy. The requirement for the CNI is to meet the administrative requirements as follows: a birth certificate date (original), photocopy of identity card (KTP) of the country of origin, copy of passport, proof of residence or letter domicile (can be a photocopy of a telephone bill or electricity), and the marriage form from the embassy concerned;

b. Photocopy of identity card (KTP) from the country of origin of the prospective husband or wife;

c. Photocopy of passport;

d. Photocopy of birth certificate;

\footnotetext{
12 "Aturan WNA Yang Akan Menikah Dengan WNI," INDONESIA.GO.ID Portal Informasi Indonesia, last modified 2019, accessed December 12, 2020, https:// indonesia.go.id/layanan/kependudukan/sosial/aturanwna-yang-akan-menikah-dengan-wni.
} 
e. Certificate not currently in the status of marriage;

f. Divorce Certificate if ever married;

g. The death certificate of the married partner if he dies;

h. Current domicile certificate;

i. Photographs $2 \times 3$ ( 4 sheets) and $4 \times$ 6 (4 sheets);

j. For marriages at the KUA, you must include a Certificate of Converts if you were previously a non-Muslim.

Until now, there is no statutory regulation that contains provisions for conducting a thorough background check or security background check for foreigners who will marry civil servants. However, it is possible that some of the vital agencies of the country already have special rules regarding this, but it would be better if there was a unification of these regulations which were set forth in a statutory regulation, so as to create a uniform arrangement of regulations. apply nationally;

3. Set the status of family allowances for civil servants.

The citizenship status of the families of civil servants who are intermarried actors has been regulated in the Citizenship Law of the Republic of Indonesia, and based on the General Elucidation, the law adheres to several principles, namely:

i. the principle ius sanguinis which determines the nationality of a person based on descent, not based on the country of birth;

ii. the principle of ius soli (law of the soil) in a limited way is the principle that determines the nationality of a person based on the country of birth, which is limited to children; iii. The principle of single nationality Is the principle that determines one nationality for each person;

iv. The principle of dual nationality limited is the principle that defines dual nationality for children.

As state civil servants, civil servants receive salaries, allowances, and facilities provided by the state. Based on Article 15 PP. 7/1977 regarding Salary Regulations for Civil Servants, apart from getting salaries and facilities, PNS also get several allowances, one of which is the family allowance. ${ }^{13}$ This family allowance is given to the main family of civil servants, namely husband / wife and children (and / or adopted children). In mixed marriages where a civil servant marries a foreigner, the provision of the family allowance can be more complicated because of the family's citizenship status. Likewise with the child allowance due to the limited dual citizenship status adopted by Indonesia based on the principles of citizenship in the Citizenship Law above. According to Article 6 paragraph (1) of the Citizenship Law, the status of limited dual citizenship is the status of

\footnotetext{
${ }^{13}$ Pasal 1 PP Nomor 51 Tahun 1992 tentang Perubahan Peraturan Pemerintah Nomor 7 Tahun 1977 tentang Peraturan Gaji Pegawai Negeri Sipil Sebagaimana Telah Diubah, Terakhir Dengan Peraturan Pemerintah Nomor 15 Tahun 1985, mengatur besaran tunjangan keluarga, untuk suami/istri dari PNS mendapat tunjangan sebesar $10 \%$ (sepuluh persen) dari gaji pokok PNS, sedangkan untuk anak yang berumur kurang dari 21 (dua puluh satu) tahun, belum pernah kawin, tidak mempunyai penghasilan sendiri, dan nyata menjadi tanggungannya, diberikan tunjangan sebesar $2 \%$ (dua persen) dari gaji pokok untuk tiaptiap anak, dengan jumlah maksimal tiga anak. Batas maksimal usia anak dapat diperpanjang sampai umur 25 (dua puluh lima) tahun apabila anak tersebut masih bersekolah.
} 
a child resulting from a mixed marriage who has not reached the age of 18 (eighteen) years and has not been married, so that the child is subject to the two state legal systems. different. The child can only choose one of the citizenship statuses of his parents when he turns 18 (eighteen) years of age or has been married before he reaches that age. Therefore, the child is still entitled to child support until the age of 18 (eighteen) years of age even though he has dual citizenship, because apart from having foreign citizenship status, he is also an Indonesian citizen. The status of the child as an Indonesian citizen is also confirmed in Article 4 letters $c$ and $d$ of the Citizenship Law, which includes Indonesian citizens who are children born from a legal marriage from an Indonesian father and a foreign mother or vice versa children born from a legal marriage of a person. foreign father and Indonesian mother. The maximum age limit for children to receive family allowances is 21 (twenty one) years and can be extended up to 25 (twenty five) years of age if they are still in school, so that if at the age of 18 (eighteen) the child decides to relinquishing their Indonesian citizenship status, the support childmust also be revoked. On the other hand, if the child maintains his Indonesian citizen status, there is also the potential for the loss of the rights of the parent who is a foreigner. In there is the principle of citizenship also Habitual Residence is home / positions. day-to-day ${ }^{14}$ It is also possible to provide child support using this prin-

14 “The Meaning of 'Ordinary Residence' and 'Habitual Residence' in the Common Law Provinces in a Family Law Context," Department of Justice, last modified ciple. Habitual residence is a solution for children who have dual citizenship, if they have a habitual residence in Indonesia that falls at the same time as one of their citizenship, which is Indonesia, then Indonesian law applies to their personal status. Meanwhile, for those who have a habitual residence outside the country, they are treated as foreigners. ${ }^{15}$ Allowance arrangements are needed so that the provision of these benefits has a solid basis. Other problems related to the provision of allowances family (and inheritance) will also arise if a divorce occurs between the civil servant and the foreigner or the death of one or both of the child's parents. Therefore, the arrangement of family allowances for civil servants for marriages mixed still needs to be specifically regulated so that there is certainty legal. and the principles of citizenship adopted by Indonesia should also be adapted into regulations regarding the provision of family allowances for civil servants who have mixed marriages.

4. Citizenship status of civil servants after marrying a foreigner.

In Article 26 paragraph (1) and (2) of the Citizenship Law, a woman who is married to a male foreigner will lose her Indonesian citizen status if according to the law of her husband's country

2015, accessed January 25, 2021, https://www.justice. gc.ca/eng/rp-pr/fl-lf/divorce/rhro_cl/p2.html.

${ }^{15}$ Leonora Bakarbessy and Sri Handajani, "Kewarganegaraan Ganda Anak dalam Perkawinan Campuran dan Implikasinya dalam Hukum Perdata Internasional," Kajian Masalah Hukum dan Pembangunan Perspektif 17, no. 1 (2012): 1, http:// jurnal-perspektif.org/index.php/perspektif/article/ view/89. 
of origin, the nationality of the wife follows the nationality of the husband and vice versa if the man- Indonesian citizens who are married to foreign women will lose their Indonesian citizenship status if according to the law of the wife's country of origin, the husband's follows the citizenship nationality of the wife as a result of the mixed marriage. However, the Citizenship Law also provides an opportunity for those who have lost their citizenship due to a mixed marriage to regain their citizenship status as Indonesian citizens. If they wish to remain an Indonesian citizen, that person can submit a statement letter regarding their wish to continue to hold the status of an Indonesian citizen to an official or representative of the Republic of Indonesia whose territory includes the residence of the woman or man, unless the application results in the status of an Indonesian citizen. dual statehood, as regulated in Article 6 paragraph (3) of the Citizenship Law. Because the Citizenship Law does not recognize the principle of dual citizenship, it will be complicated if the petition causes the civil servant to have dual citizenship status. So that one solution that can be given in such a situation is to give up his citizenship status as an Indonesian citizen. Because these PNS relinquish their Indonesian citizenship status, the PNS automatically does not fulfill the requirements as PNS because they are no longer Indonesian citizens. This of course can be detrimental to the State because it loses its employees due to mixed marriages. Therefore, it is necessary to also regulate related to this matter so that the State can minimize the risk of losing employees due to mixed marriages.

Apart from the problems above, there are also common problems that can arise in mixed marriages, namely differences in religion and belief. The international community is a plural society and each of them has the freedom to embrace or even not embrace any religions and beliefs. Based on the applicable Indonesian law, as stated in Law no. 1/1974, Article 2 paragraph (1) states that a marriage is considered valid if it fulfills it according to their respective religions and beliefs. This certainly makes it difficult and does not give justice to couples of different faiths, especially from the administrative side. ${ }^{16}$ In practice, many couples have different religions, one of which is forced to leave their religion and follow the religion of their partner. This also becomes a contradiction considering Article 29 paragraph (2) of the 1945 Constitution, in which State guarantees the freedom of each of the inhabitants to embrace their respective religions and to worship according to their religion and belief. In addition, it is emphasized in the explanation of Article 2 of Law no. 1/1974 that there is no marriage outside the religious law. However, in reality, there are mixed interreligious marriages that are carried out abroad and their marriages are still valid after returning to Indonesia. In the case of interreligious mixed marriages, it is not carried out according to religious law. ${ }^{17}$

\footnotetext{
${ }^{16}$ Ni Putu Diah Arsari, Tedi Erviantono, and I Ketut Winaya, "Sistem Administrasi Perkawinan Beda Negara Pada Dinas Kependudukan Dan Pencatatan Sipil Kota Denpasar," Citizen Charter 1, no. 1 (2016): 5, https://ojs.unud.ac.id/index.php/citizen/article/ view/24316.

${ }^{17}$ Yunanto, "Pembaharuan Hukum Perkawinan Indonesia," Diponegoro Private Law Review 3, no. 1
} 
The Ideal Law Application for Mixed Marriages Between Civil Servants and Foreigners

According to Gustav Radbruch, in law there are three basic values, namely justice (gerechtigkeit), benefit (zweck-massigkeit), and legal certainty (rechts-sicherheit). ${ }^{18}$ Therefore, the ideal mixed marriage arrangement is one that can fulfill these basic values because it can more concretely protect the perpetrators of mixed marriages. Law also aims not only to create order, but also to achieve justice that varies in content and size, according to society and its era. ${ }^{19}$ So, the interests of the have not been accommodated perpetrators of mixed marriages between civil servants and foreigners, causing these basic valuesand legal objectives to have not been achieved.

The ideal application of the law of mixed marriage between civil servants and foreigners is to revise Government Regulation no. 45/1990 concerning Amendments to Government Regulation No. 10 of 1983 concerning Permits for Marriage and Divorce for Civil Servants and PP No. 7/1977 regarding Salary Regulations for Civil Servants by adding articles that regulate mixed marriages. The application of the PNS mixed marriage arrangement is necessary so that there is uniformity that applies nationally and makes it easier for mixed marriage actors, especially civil ser-

(2018): 265, https://ejournal2.undip.ac.id/index.php/ dplr/article/view/3828.

${ }^{18}$ Mario Julyano and Aditya Yuli Sulistyawan, "Pemahaman Terhadap Asas Kepastian Hukum Melalui Konstruksi Penalaran Positivisme Hukum," Jurnal Crepido Jurnal Mengenai Dasar-Dasar Pemikiran Hukum: Filsafat dan Ilmu Hukum 1, no. 1 (2019): 14, https://ejournal2.undip.ac.id/index.php/ crepido/article/view/6325.

19 Mochtar Kusumaatmadja, Konsep-Konsep Hukum dalam Pembangunan, Cetakan II (Bandung: PT Alumni, 2006), 3. vants, to access and understand their rights and obligations. In addition, the mixed marriage arrangement must contain at least the requirements for foreigners before being able to marry civil servants, conducting a background check for foreigners who will marry civil servants from ministries or vital state institutions, regulating the status of civil servant family allowances, and affirming the status of civil servants after marrying a foreigner.

\section{CONCLUSION}

absence of regulations that specifically regulate mixed marriages between civil servants and foreigners, raises the urgency to form a statutory regulation that regulates this matter. This is because the status of civil servants who are servants state civil has a responsibility not only for themselves, but also for the state, so they must always becareful in everything they do, including fostering a household, let alone doing it through a mixed marriage with foreigners. With the arrangement special formarriages mixed between civil servants and foreigners, it can accommodate all things including the rights and obligations of the perpetrators of mixed marriages. The mixed marriage arrangement will serve as guidance for civil servants in fulfilling their rights and obligations as civil servants even though they are married to foreigners.

The application of regulations on marriage between mixed civil servants and foreigners is ideal by revising Government Regulation no. 45/1990 concerning Amendments to Government Regulation No. 10/1983 concerning Marriage and Divorce Permits for Civil Servants and PP No. 7/1977 regarding Salary Regulations for Civil Servants so that there is uniformity that applies nationally and makes it easier for actors of mixed marriage, espe- 
cially civil servants, to access and understand their rights and obligations.

\section{BIBLIOGRAPHY}

\section{Books}

Kaharuddin. Nilai-Nilai Filosofi Perkawinan: Menurut Hukum Perkawinan Islam dan Undang-Undang RI Nomor 1 Tahun 1974 tentang Perkawinan. Jakarta: Mitra Wacana Media, 2015.

Kusumaatmadja, Mochtar. Konsep-Konsep Hukum dalam Pembangunan. Cetakan II. Bandung: Alumni, 2006.

Sulistiani, Siska Lis. Kedudukan Hukum Anak: Hasil Perkawinan Beda Agama Menurut Hukum Positif dan Hukum Islam. Bandung: Refika Aditama, 2015.

Pabbu, Amiruddin and Rahman Syamsuddin. Pengantar Ilmu Hukum. Jakarta: Mitra Wacana Media, 2014.

\section{Journal}

Arsari, Ni Putu Diah, Tedi Erviantono, and I Ketut Winaya. "Sistem Administrasi Perkawinan Beda Negara Pada Dinas Kependudukan Dan Pencatatan Sipil Kota Denpasar." Citizen Charter 1, no. 1 (2016): 5. https://ojs.unud.ac.id/index.php/citizen/ article/view/24316.

Bakarbessy, Leonora, and Sri Handajani. "Kewarganegaraan Ganda Anak Dalam Perkawinan Campuran Dan Implikasinya Dalam Hukum Perdata Internasional." Kajian Masalah Hukum dan Pembangunan Perspektif 17, no. 1 (2012): 1. http://jurnalperspektif.org/index.php/perspektif/ article/view/89.

Harahap, Sayaman. "Penerapan Ketentuan Pasal 21 Ayat (3) UUPA Tentang Kepemilikan Tanah Bagi WNI Dalam Perkawinan Campuran." Jurnal IUS Kajian Hukum dan Keadilan 4, no. 3
(2016): 440. https://jurnalius.ac.id/ojs/ index.php/jurnalIUS/article/view/328.

Julyano, Mario, and Aditya Yuli Sulistyawan. "Pemahaman Terhadap Asas Kepastian Hukum Melalui Konstruksi Penalaran Positivisme Hukum." Jurnal Crepido Jurnal Mengenai Dasar-Dasar Pemikiran Hukum: Filsafat dan Ilmu Hukum 1, no. 1 (2019): 14. https://ejournal2.undip.ac.id/ index.php/crepido/article/view/6325.

Pompe, S. "Mixed Marriages in Indonesia: Some Comments on The Law and The Literature." Bijdragen tot de Taal-, Land-en Volkenkunde 144, no. 2/3 (April 1, 1988): 261. http://www.jstor.org/ stable/27863947.

Rifai, Ahmad, Ibnu Sodiq, and Abdul Muntholib. "Sejarah Undang-Undang Perkawinan Atas Pendapat Hingga Pertentangan Dari Masyarakat Dan Dewan Perwakilan Rakyat Tahun 1973-1974." Journal of Indonesian History 4, no. 1 (2015): 8. https://journal.unnes.ac.id/sju/ index.php/jih/article/view/18401.

Wibisana, Wahyu. "Pernikahan Dalam Islam." Jurnal Pendidikan Agama Islam -Ta'lim 14, no. 2 (2016): 185-193. http://jurnal.upi.edu/taklim/view/4607/ PERNIKA HA N \% 20 D A L A M \% 20 ISLAM.

Widanarti, Herni, "Akibat Hukum Perkawinan Campuran Terhadap Harta Perkawinan (Penetapan Pengadilan Negeri Denpasar No: 536/Pdt.P/2015/PN.Dps.).” Diponegoro Private Law Review 2, no. 1 (2018): 161-169. https://ejournal2.undip. ac.id/index.php/dplr/article/view/2827.

Yunanto. "Pembaharuan Hukum Perkawinan Indonesia." Diponegoro Private Law Review 3, no. 1 (2018): 265. https:// ejournal2.undip.ac.id/index.php/dplr/ 
article/view/3828.

\section{Internet}

"Aturan WNA Yang Akan Menikah Dengan WNI." INDONESIA.GO.ID Portal Informasi Indonesia. Last modified 2019. Accessed December 12, 2020. https:// indonesia.go.id/layanan/kependudukan/ sosial/aturan-wna-yang-akan-menikahdengan-wni.

“The Meaning of 'Ordinary Residence' and 'Habitual Residence' in the Common Law Provinces in a Family Law Context." Department of Justice. Last modified 2015. Accessed January 25, 2021. https:// www.justice.gc.ca/eng/rp-pr/fl-lf/divorce/ rhro_cl/p2.html.

\section{Thesis}

Syamsualam, Andi. "Usia Perkawinan Dalam Perspektif Filsafat Hukum Dan Kontribusinya Bagi Pengembangan Hukum Perkawinan Indonesia." Kepaniteraan Mahkamah Agung RI, 2011. https://kepaniteraan.mahkamahagung. go.id/index.php/kegiatan/6-artikel/artikelhakim-agung/188-usia-perkawinandalam-perspektif-filsafat-hukum-dankontribusinya-bagi-pengembanganhukum-perkawinan-indonesia-dr-h-andisyamsualam-sh-mh.

\section{Law and Regulation}

Undang-Undang Dasar Negara Republik Indonesia Tahun 1945

Undang-undang tentang Dasar Pokok-Pokok Agraria, UU Nomor 5 Tahun 1960, LN Tahun 1960 Nomor 104, TLN Nomor 2043 Undang-Undang tentang Perkawinan, UU Nomor 1 Tahun 1974, LN Tahun 1974 Nomor 1, TLN Nomor 3019

Undang-Undang tentang Hak Asasi Manusia, UU Nomor 39 Tahun 1999, LN Tahun 1999 Nomor 165, TLN Nomor 3886
Undang-Undang tentang Kewarganegaraan Republik Indonesia, UU Nomor 12 Tahun 2006, LN. Tahun 2006 Nomor 63, TLN Nomor 4634

Undang-Undang tentang Keimigrasian, UU Nomor 6 Tahun 2011, LN Tahun 2011 Nomor 52, TLN Nomor 5216

Undang-Undang tentang Aparatur Sipil Negara, UU Nomor 5 Tahun 2014, LN Tahun 2014 Nomor 6, TLN Nomor 5494

Peraturan Pemerintah tentang Perubahan Peraturan Pemerintah Nomor 7 Tahun 1977 tentang Peraturan Gaji Pegawai Negeri Sipil Sebagaimana Telah Diubah, Terakhir Dengan Peraturan Pemerintah Nomor 15 Tahun 1985, PP Nomor 51 Tahun 1992 Regeling op de Gemengde Huwelijken (GHR) Peraturan tentang Perkawinan Campuran Penetapan Raja Tanggal 29 Desember 1896 No. 23-Stbl 1898 No. 158, Dir. Dandit. Dengan Stbl. 901/348, 1902/311, $1907 / 205,1918 / 30,159,160$, dan 161,1919/81, dan 816,1931/168 jo. 423 